\title{
EVALUASI PROSES KEBIJAKAN PERUMAHAN TIDAK TERTATA (STUDI KASUS: PASAR IKAN PENJARINGAN, JAKARTA UTARA)
}

\author{
Fany Namirah Kurnia ${ }^{1)}$, Parino Rahardjo ${ }^{2)}$ \\ 1)Program Studi S1 PWK, Fakultas Teknik, Universitas Tarumanagara, fanykurnia78@gmail.com \\ 2)Program Studi S1 PWK, Fakultas Teknik, Universitas Tarumanagara, parinor19@gmail.com
}

\begin{abstract}
Abstrak
Keberadaaan permukiman kumuh merupakan fenomena yang umum terjadi di kawasan perkotaan di Indonesia khususnya DKI Jakarta. Umumnya permukiman kumuh ini dihuni oleh Masyarakat Berpenghasilan Rendah (MBR) sehingga muncul permukiman kumuh yang disebabkan oleh penggunaan lahan secara ilegal. Salah satu upaya pemerintah dalam mengatasi permasalahan hunian ilegal ini adalah dengan mengeluarkan kebijakan relokasi. Akan tetapi pada praktiknya, sering terjadi penolakan dari pihak terdampak. Salah satu kebijakan relokasi yang mendapat penolakan tersebut adalah relokasi warga Pasar Ikan Pejaringan ke Rusunawa. Pada penilitian ini peneliti bertujuan untuk mengetahui proses relokasi di Pasar Ikan Penjarigan serta mengetahui faktor-faktor yang memepengaruhi proses tersebut dilihat dari bagaimana koordinasi antar pihak yang terlibat. Penelitian ini menggunakan metode kualitatif dengan menggunakan analisis deskriptif dan dari hasil yang didapatkan diketahui bahwa proses kebijakan relokasi di Pasar Ikan ini masih kurang baik. Hal ini dipegaruhi oleh tidak adanya prosedur yang jelas mengenai relokasi di Jakarta serta beberapa faktor lain seperti kurangnya Sumber Daya, Fasiilitas, dan Sikap dari pelaksana.
\end{abstract}

Kata kunci: Kebijakan Relokasi; Pasar Ikan Penjaringan; Relokasi

\begin{abstract}
The existence of slum area is a phenomenon that is common in urban areas in Indonesia, especially DKI Jakarta. Generally these slums are inhabited by Low-Income Communities $(M B R)$ so that slums appear that are caused by illegal land use. One of the government's efforts in overcoming the problem of illegal occupancy is by implementing a relocation policy. However, in practice, there is often rejection from affected parties. One of the relocation policies that received the rejection was the relocation of residents of the Network Fish Market to Rusunawa. In this research the researcher aims to find out the relocation process in the Penjaringan Fish Market and find out the factors that influence the process seen from how the coordination between the parties involved. This study uses descriptive qualitative methods and from the results obtained it is known that the relocation policy process in the Fish Market is still not good. This was influenced by the absence of clear procedures regarding relocation in Jakarta as well as several other factors such as lack of resources, facilities, and attitudes of the implementers.
\end{abstract}

Keywords: Penjaringan Fish Market; Relocationl; Relocation Policy

\section{PENDAHULUAN}

Kawasan permukiman kumuh merupakan fenomena yang umum terjadi di kawasan perkotaan di Indonesia khususnya Ibukota DKI Jakarta. Salah satu kawasan di Jakarta yang dijadikan kawasan hunian ilegal oleh masyarakat MBR adalah Kawasan Pasar Ikan, Penjaringan, Jakarta Utara. Kawasan Pasar Ikan ini merupakan tanah yang dimiliki oleh dua pihak yaitu PD. Pasar Jaya dan Pemda DKI Jakarta. Pada tahun 2016 Pemda DKI Jakarta mengeluarkan kebijakan untuk menggusur daerah tersebut dan merelokasi warga yang berada di kawasan Pasar Ikan Penjaringan ke Rusunawa yang ada di Jakarta. Revitalisasi Kawasan Kota Tua, mengembangkan ekonomi Kawasan Pasar Ikan Penjaringan, mengatasi banjir rob, sertan mewujudkan penghidupan yang lebih baik untuk warga. 


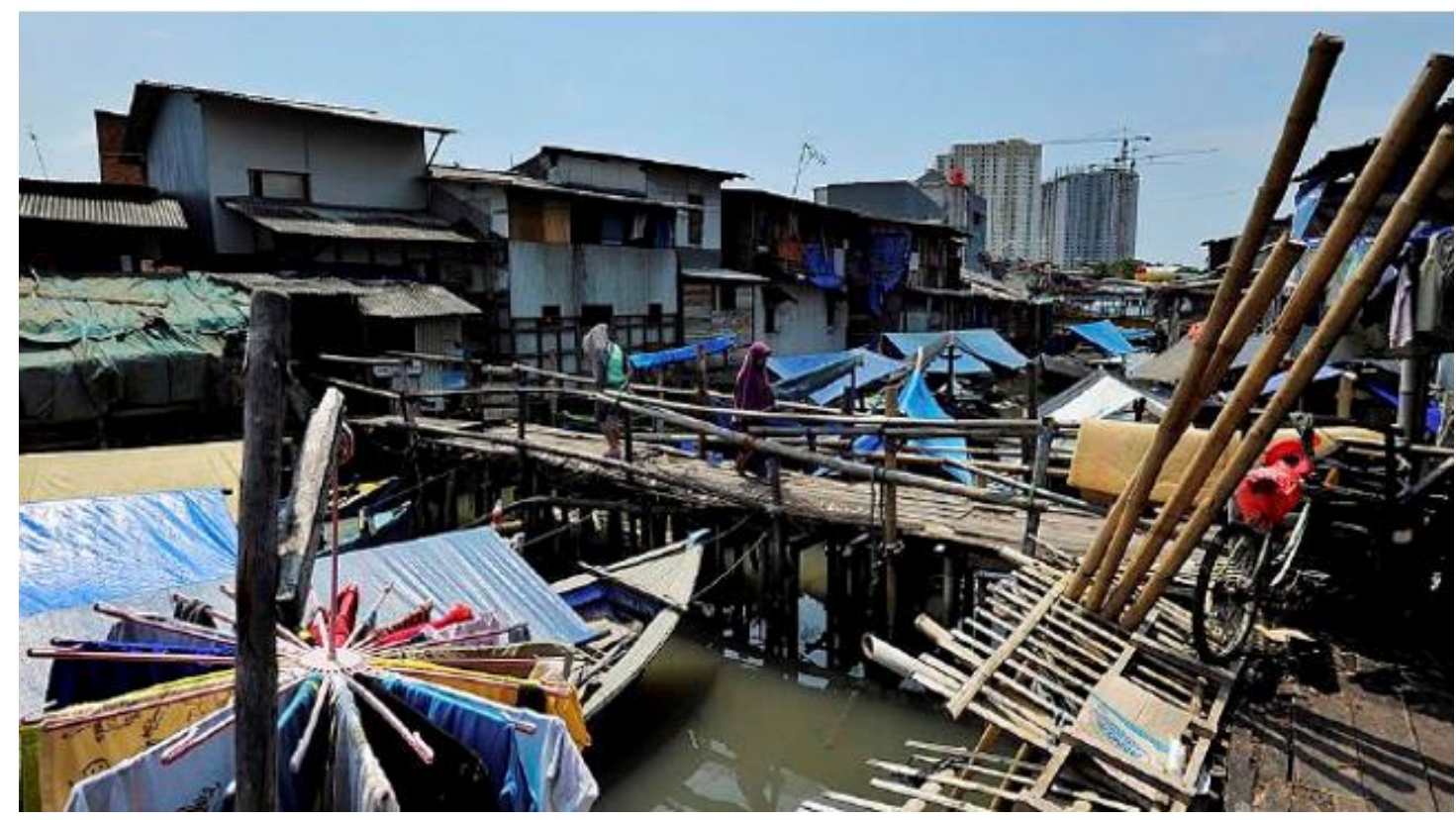

Gambar 1. Kondisi Permukiman Pasar Ikan Sebelum Relokasi

Sumber: Google

Berdasarkan infromasi yang diperoleh dari situs resmi pemerintah DKI Jakarta diketahui bahwa Kawasan Pasar Ikan dibangun dalam waktu yang cukup sudah lama yaitu sejak 1631 (Pada waktu itu disebut Vischmarkt). Pada tahun 1980-an Kawasan tersebut mulai dihuni oleh masyarakat baik yang merupakan masyarakat asli Jakarta maupun yang merupakan pendatang. Seiring berjalannya waktu masyarakat yang menempati kawasan ini terus bertambah. Warga yang tinggal di Kawasan Pasar Ikan Penjaringan ini merupakan warga DKI Jakarta dan pendatang yang berasal dari Sulawesi, Sumatera, dan Maluku. Warga Pasar Ikan didominasi oleh warga yang berprofesi sebagai nelayan, penjual ikan, memiliki kios dan usaha kontrakan. Banyak warga yang menjadikan rumahnya sebagai kontrakan inilah yang menyebabkan padatnya masyarakat yang menduduki wilayah tersebut.

Kawasan Pasar Ikan Penjaringan merupakan daerah milik pemerintah yang seharusnya difungsikan sebagai ruang terbuka hijau namun pada saat itu dipenuhi oleh bangunan hunian dan tempat usaha PD Pasar Jaya yang disalahgunakan menjadi tempat tinggal. Berangkat dari kondisi tersebut maka Gubernur DKI Jakarta Basuki Tjahaja Purnama (2016) mengeluarkan kebijakan untuk merelokasi warga Pasar Ikan Penjaringan ke dua Rusunawa yang telah dipersiapkan. Warga yang terdampak kebijakan dan akan terkena relokasi adalah warga yang berada di RT 001, 002, 011, dan 012 / RW 004.

Pasar Ikan telah terbentuk dalam waktu yang cukup lama (sejak 1846) sehingga keberadaan komunitas yang telah lama melangsungkan kehidupannya di tempat tersebut menyebabkan pelaksanaan relokasi tidak mudah dilakukan sehingga pemerintah melakukan pemindahan secara paksa pada tahun 2016. Kawasan permukiman kumuh Pasar Ikan yang digusur seluas 3,3 Hektar yang mencakup RT 1, 2, 11, dan 12 yang berada di RW $04^{1}$ dengan jumlah KK yang terdampak sebesar 396 KK namun yang berhasil direlokasi ke Rusun sebanyak 341 KK dengan jumlah bangunan yang digusur sebanyak 893 bangunan.

\footnotetext{
${ }^{1}$ Data Kecamatan Penjaringan
} 


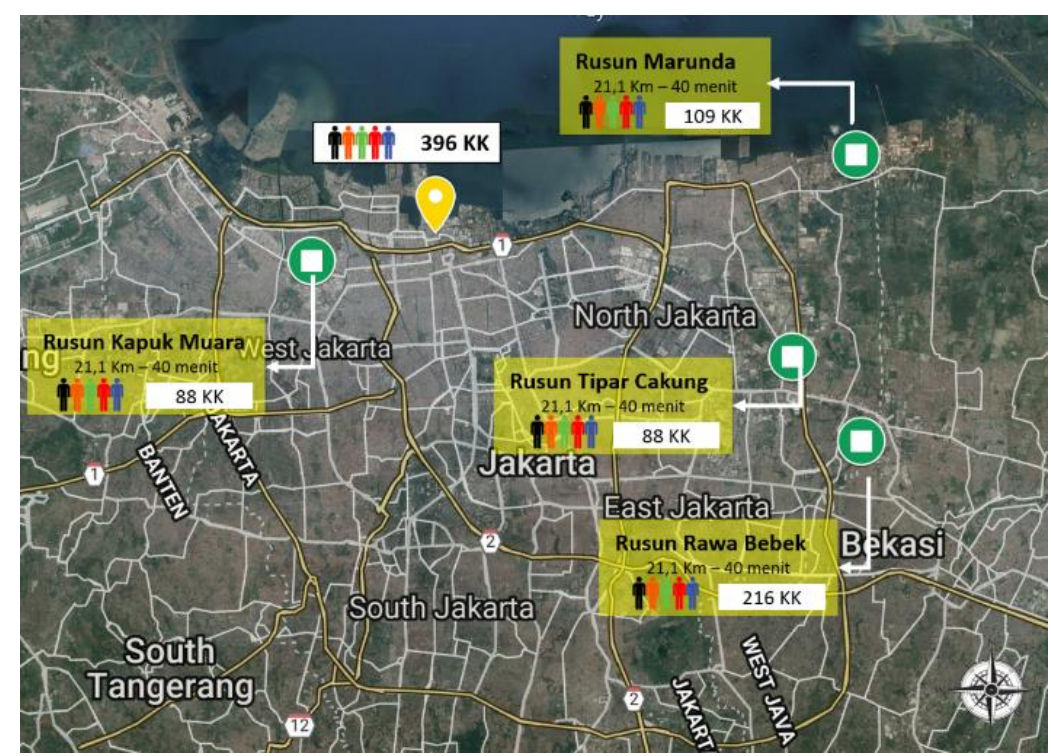

Gambar 2. Jumlah KK yang tertampung dan Jarak Pasar Ikan Penjaringan ke Rusun Tujuan Relokasi

Sumber : Penulis, 2019

Warga yang akan terdampak nanti dipindahkan ke empat Rusun berbeda yaitu Rusunawa Marunda, Rawa Bebek, Kapuk Muara, dan Tipar Cakung. Rusun Marunda dan Rawa Bebek dianggap jauh dari lokasi awal mereka sedangkan mereka masih bekerja di lokasi dekat tempat tinggal mereka sedangkan Rusun Kapuk Muara dan Tipar Cakung kuota yang disediakan hanya sedikit. Berikut adalah jarak dari Pasar Ikan Penjaringan meruju ke Rusun.

Kebijakan relokasi warga Pasar Ikan Penjaringan ke Rusunawa ini telah dilaksanakan pada April 2016 namun kebijakan tersebut belum dapat memindahkan seluruh warga Pasar Ikan Penjaringan karena hingga sekarang masih terdapat warga yang menempati daerah tersebut. Hingga saat ini belum ada penelitian terkait kebijakan relokasi di Pasar Ikan Penjaringan ini. Penelitian ini dilakukan untuk melihat sejauh mana bagaimana proses relokasi di Pasar Ikan Penjaringan, koordinasi dari setiap pihak yang terlibat sehingga dapat diketahui faktor yang mempengaruhi keberhasilan kebijakan relokasi masyarakat Pasar Ikan Penjaringan yang dipindahkan ke Rusunawa guna untuk mengevaluasi Proses Kebijakan Relokasi Pasar Ikan Penjaringan.

\section{KAJIAN LITERATUR}

\section{Relokasi}

Relokasi dalam konteks perumahan dan permukiman dapat diartikan sebagai pemindahan dari suatu lokasi permukiman ke lokasi permukiman yang baru. Menurut Maria (2005:92) relokasi dapat menjadi satu alternatif yang dapat menjadi kesempatan waraga terdampak untuk menata kembali dan melajutkan kehidupannya di tempat yang baru.

Relokasi harus dilakukan dengan perencanaan yang matang dan komprehensif agar tujuan dapat tercapai. Kebijakan relokasi memiliki prinsip dasar yaitu government responsibility, resettler's participation, and the hosts population (Cernea, 1988:41).

Dalam implementasinya di Indonesia, jarang sekali terdapat program relokasi yang berhasil. Aspek-aspek yang menyebabkan relokasi tidak berhasil yaitu ketidakcukupan lokasi-lokasi baru (nadequacy of new sites), jarak dari mata pencaharian dan jaringan sosial (distance from livelihoods and social networks), tata letak permukiman yang tidak sesuai dengan budaya setempat (socio-culturally inappropriate settlement layouts), kurangnya partisipasi masyarakat (lack of community participation) dan di bawah anggaran biaya relokasi (under budgeting of relocation cost). 


\section{Prosedur Relokasi}

Pada proses persiapan dalam pelaksanaan kebijakan relokasi maka prosedur pada tahap pra-penggusuran akan dilihat berdasarkan Peraturan Presiden No.71/2012 tentang Penyelenggaraan Tanah Bagi Pembanguanan untuk Kepentingan umum, serta Peraturan Kepala BPN RI No.5 tentang Petunjuk Teknis Pengadaan Tanah. Berikut adalah tahap yang harus dilakukan pemerintah dalam pembebasan lahan:

Tabel 1. Prosedur Persiapan Relokasi

\begin{tabular}{ll}
\hline \multicolumn{1}{c}{ Tahapan } & \multicolumn{1}{c}{ Kriteria } \\
\hline Perencanaan (Pasal & Pembuatan Dokumen (Kajian) untuk disampaikan ke Gubernur untuk bahan \\
5 Perpres 71/2012) & pemberitahuan kepada warga terdampak \\
\hline & $\begin{array}{l}\text { Pemberitahuan (Pasal 12,13,14,15 Perpres 71/2012) } \\
\text { (Komunikasi) }\end{array}$ \\
\cline { 2 - 2 } & Pendataan Awal Lokasi (Perkap BPN No.5/2012 Pasal 7 dan 10) \\
\cline { 2 - 2 } Persiapan & $\begin{array}{l}\text { Konsultasi Publik Rencana Pembangunan (pasal 23 UU no.02/2012 \& } \\
\text { Bagian keempat perpres 71/2012) }\end{array}$ \\
\cline { 2 - 2 } & Penilaian Ganti Rugi (Bab IV Perpres 71/2012) \\
\cline { 2 - 2 } & Penyerahan Tanah \\
\hline
\end{tabular}

Sumber : Penulis, 2019

Dalam melihat prosedur relokasi pada penelitian ini dilihat berdasarkan panduan United Nation Basic Principles and Guidelines on Development-Based Evictions. Prinsip utama dari panduan di atas adalah memastikan agar warga terdampak program tidak mengalami penurunan kesejahteraan dari lokasi tempat tinggal sebelumnya dibandingkan dengan tempat tinggal yang baru. Panduan prosedur pelaksanaan program relokasi akan dibagi menjadi tiga tahap yaitu pra-penggusuran, pelaksanaan penggusuran, dan pasca-penggusuran.

Tabel 2. Prosedur Tahapan Pelaksanaan Relokasi

\begin{tabular}{|c|c|c|c|c|}
\hline \multicolumn{5}{|c|}{ Petunjuk Pelaksanaan } \\
\hline & Pra-Penggusuran & & Penggusuran & Pasca-Penggusuran \\
\hline (1) & $\begin{array}{l}\text { Mencari alternatif lain } \\
\text { selain melakukan } \\
\text { penggusuran }\end{array}$ & (1) & $\begin{array}{l}\text { Perwakilan pemerintah (1) } \\
\text { wajib memantau } \\
\text { pelaksanaan penggusuran }\end{array}$ & $\begin{array}{l}\text { Pelaku pembangunan wajib } \\
\text { menjamin ketersediaan } \\
\text { kebutuhan warga }\end{array}$ \\
\hline (2) & $\begin{array}{lr}\text { Membuktikan } & \text { bahwa } \\
\text { penggusuran } & \text { tidak } \\
\text { dapat dihindari } & \end{array}$ & (2) & $\begin{array}{l}\text { Pelaksanaan penggusuran (2) } \\
\text { harus dilaksanakan } \\
\text { dengan cara yang tidak } \\
\text { melanggar hak asasi : } \\
\text { - Tidak adanya kekerasan } \\
\text { dan pakasaan } \\
\text { - Pengarahan aparat harus } \\
\text { proporsional }\end{array}$ & $\begin{array}{l}\text { Pemerintah wajib menjamin } \\
\text { perlindungan kepada warga } \\
\text { kelompok rentan: } \\
\text { - Lanjut Usia } \\
\text { - Difabel } \\
\text { - Perempuan } \\
\text { - Anak }\end{array}$ \\
\hline (3) & $\begin{array}{l}\text { Musyawarah dengan } \\
\text { publik dan warga yang } \\
\text { terdampak }\end{array}$ & & $\begin{array}{l}\text { Adanya dokumentasi yang (3) } \\
\text { lengkap dan transparan } \\
\text { mengenai pelaku } \\
\text { pembangunan dan warga } \\
\text { terdampak }\end{array}$ & $\begin{array}{lrr}\text { Tempat relokasi } & \text { wajib } \\
\text { memenuhi kriteria } & \text { tempat } \\
\text { tinggal yang layak } & \end{array}$ \\
\hline (4) & $\begin{array}{l}\text { Menginformasikan } \\
\text { secara transparan dan } \\
\text { lengkap mengenai } \\
\text { alasan penggusuran dan } \\
\text { rencana pembangunan }\end{array}$ & & $\begin{array}{l}\text { Penggusuran tidak dapat (4) } \\
\text { dilaksanakan pada kondisi- } \\
\text { kondisi tertentu : } \\
\text { - Cuaca buruk } \\
\text { - Malam hari } \\
\text { - Hari raya tradisional atau } \\
\text { keagamaan } \\
\text { - Menjelang pemilu } \\
\text { - Menjelang ujian sekolah }\end{array}$ & $\begin{array}{l}\text { Kompensasi harta benda } \\
\text { harus diberikan kepada warga } \\
\text { yang terdampak }\end{array}$ \\
\hline
\end{tabular}




\begin{tabular}{|c|c|c|c|}
\hline \multicolumn{4}{|c|}{ Petunjuk Pelaksanaan } \\
\hline \multicolumn{2}{|r|}{ Pra-Penggusuran } & Penggusuran & Pasca-Penggusuran \\
\hline (5) & $\begin{array}{l}\text { Menjamin adanya (5) } \\
\text { alternatif tempat tinggal } \\
\text { yang memadai dan } \\
\text { sesuai standar }\end{array}$ & $\begin{array}{l}\text { Negara wajib menjamin (5) } \\
\text { agar tidak ada kekerasan } \\
\text { terutama pada kelompok } \\
\text { perempuan dan anak-anak }\end{array}$ & $\begin{array}{l}\text { Pemerintah wajib menjamin } \\
\text { hak warga atas bantuan } \\
\text { hukum }\end{array}$ \\
\hline (6) & $\begin{array}{l}\text { Penilaian terhadap } \\
\text { dampak penggusuran }\end{array}$ & $\begin{array}{lr}\text { Harta benda } & \text { warga } \\
\text { terdampak } & \text { wajib } \\
\text { dilindungi } & \\
\end{array}$ & \\
\hline (7) & $\begin{array}{lr}\text { Memberi batas waktu } & \text { (7) } \\
\text { yang cukup untuk warga } & \\
\text { terdampak } & \text { untuk } \\
\text { mengamankan } & \text { harta } \\
\text { bendanya } & \end{array}$ & $\begin{array}{l}\text { Tidak boleh } r \text { ada } \\
\text { pemaksaan dari } \\
\text { pembangunan } \\
\text { menghancurkan tempat } \\
\text { tinggal warga terdampak }\end{array}$ & \\
\hline (8) & $\begin{array}{l}\text { Relokasi } \quad \text { wajib } \\
\text { dilaksanakan sebelum } \\
\text { eksekusi/penggusuran }\end{array}$ & & \\
\hline
\end{tabular}

Sumber : Penulis, 2019

\section{Koordinasi Aktor Pelaksanaan Kebijakan Relokasi}

Koordinasi dapat diartikan sebagai pengaturan yang tertib dari kumpulan atau gabungan usaha, untuk menciptakan kesatuan tindakan dalam mencapai tujuan bersama ${ }^{2}$. Sebuah koordinasi merupakan komponen yang sangat penting dalam mencapai tujuan sebuah kebijakan agar sesuai dengan apa yang telah direncanakan. Koordinasi juga dapat diartikan sebagai upaya agar tercipatanya keselarasan kerja antar semua pihak sebagai pemangku kepentingan sehingga tidak terjadi kesimpang siuran, saling tumpang tindih agar suatu kebijakan dapat dilaksanakan secara efektif dan efisien.

Menurut Syafrudin (1993:13) bahwa mekanisme koordinasi meliputi antara lain: kebijaksanaan, yaitu sebagai arah tujuan, rencana, yaitu tertuang cara melaksanakan, waktu pelaksanan, orang yang melaksanakan, prosedur dan tata kerja yaitu berisi siapa melakukan apa, kapan dilaksanakan, dan dengan siapa harus berhubungan yang dibuat dalam bentuk petunjuk pelaksanaan.

Dalam pelaksanaan kebijakan untuk mencapai tujuan dibutuhkan kinerja yang baik. faktorfaktor yang dapat mempengaruhi kinerja suatu kebijakan yaitu faktor sumber daya, komunikasi, dan sikap dari para pelaksana kebijakan tersrbut seperti yang diungkapkan oleh Grindle dalam Wibawa (1994:22), Van Meter dan Van Horn (1975), serta Edward III dalam Widodo (2011:98), sebagai berikut :

Tabel 3. Faktor -Faktor yang Mempengaruhi Kebijakan Publik

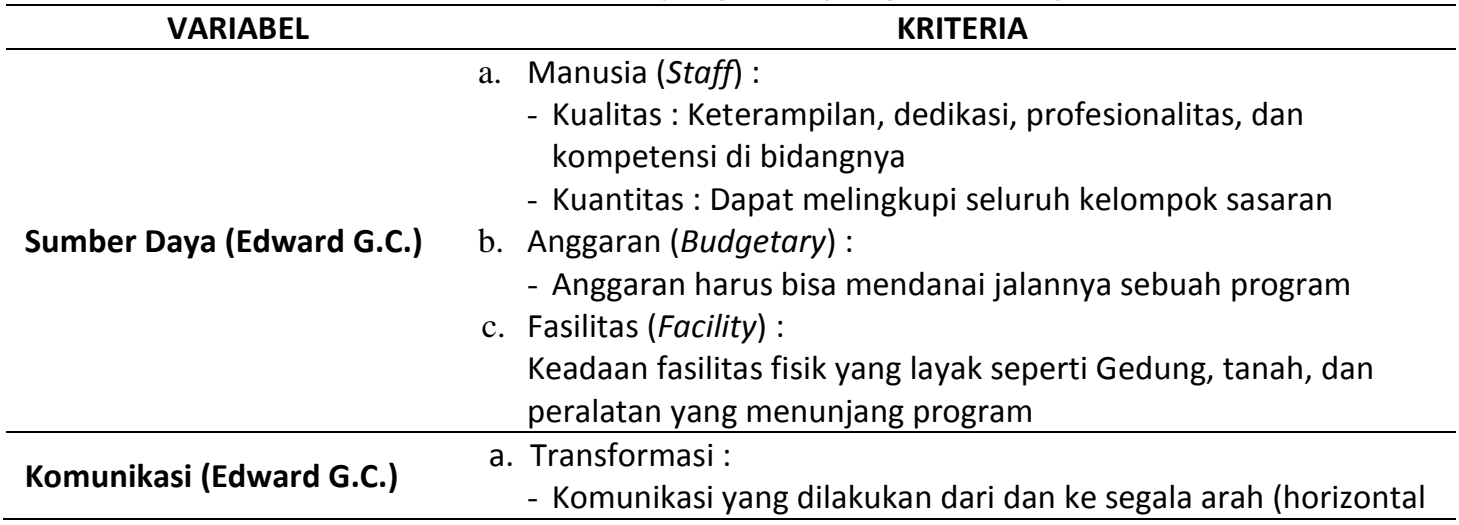

2 Prof. Dr. Ateng Syafruding, SH, Pengaturan Koordinasi Pemerintahan di Daerah, 1993, Bandung Citra Aditya Bhakti, Hal : 10 


\begin{tabular}{ll}
\hline \multicolumn{1}{c}{ VARIABEL } & \multicolumn{1}{c}{ KRITERIA } \\
\hline & \\
& b. Kejelasan : \\
& - Jelas \\
& - Mudah dipahami \\
& c. Konsistensi : \\
& Harus konsisten agar tidak menimbulkan kebingungan \\
\hline \multirow{3}{*}{ Sikap Pelaksana } & a. Kekuasaan \\
(Van Meter dan Van Horn) & b. Pemahanan Tujuan Kebijakan \\
& c. Ketaatan terhadap Prosedur \\
& d. Peran dan Tanggung Jawab \\
\hline
\end{tabular}

Sumber : Penulis, 2019

\section{METODE}

Metode penelitian yang digunakan dalam melakukan penelitian ini adalah metode diskriptif dengan menggunakan analisis kualitatif. Menurut Hadari Nawawi (1990: 64) metode deskriptif lebih berpusat pada masalah-masalah atau fenomena-fenomena yang ada pada saat penelitian atau masalah yang bersifat aktual, kemudian menggunakan fakta-fakta tentang masalah yang diteliti diiringi dengan interpretasi rasional yang akurat.

Penelian dengan judul Evaluasi Proses Kebijakan Relokasi Perumahan Tidak Tertata (Studi Kasus : Pasar Ikan Penjaringan) dilakukan atas dasar ketertarikan penulis atas penolakan keras warga terdampak terhadap kebijakan relokasi tersebut. Metode pengumpulan data dala penelitian ini adalah melalui dokumen-dokumen proses relokasi di Pasar Ikan Penjaringan serta melalui wawancara (indepth interview) yang dilakukan terhadap pihak-pihak terkait (purposive sampling) yang kemudian akan dianalisis dan disajikan dalam bentuk deskriptif agar dapat menjawab pertanyaan penelitian. Dalam menganalisis, peneliti membagi kedalam tiga fokus analisis yaitu :

a) Kebijakan Relokasi Pasar Ikan Penjaringan

b) Koordinasi dalam Proses Kebijakan Relokasi Pasar Ikan Penjaringan
a. Sumber Daya
b. Komunikasi
c. Sikap Pelaksana
d. Prosedur dan Pelaksanaan Proses Relokasi

c) Evaluasi Kebijakan Relokasi Pasar Ikan Penjaringan

Dari ketiga analisis di atas diharapkan dapat mendeskripsikan secara lengkap mengenai proses relokasi di Pasar Ikan Penjaringan serta dapat menjadi input untuk upaya relokasi di masa yang akan datang.

\section{DISKUSI DAN HASIL}

\section{Kebijakan Relokasi Pasar Ikan Penjaringan}

Dalam pembuatan kebijakan relokasi Pasar Ikan Penjaringan ini terdapat beberapa aturan dan kebijakan yang menjadi landasan hukum dalam pengambilan keputusan relokasi.

Tabel 3. Aturan dan Kebijakan sebagai Landasan Kebijakan Relokasi Pasar Ikan Penjaringan

\begin{tabular}{ll}
\hline \multicolumn{1}{c}{ Aturan dan Kebijakan } & \multicolumn{1}{c}{ Isi Aturan dan Kebijakan } \\
\hline $\begin{array}{l}\text { Peraturan Gubernur Provinsi DKI Jakarta No.36 } \\
\text { tahun 2014 }\end{array}$ & $\begin{array}{l}\text { Revitalisasi Wisata Bahari (Kawasan wisata rohani } \\
\text { dan penunjang di sekitar Masjid Luar Batang) }\end{array}$ \\
\hline $\begin{array}{l}\text { Instruksi Gubernur Provinsi DKI Jakarta No.68 } \\
\text { tahun 2014 } \\
\text { Instruksi Gubernur DKI Jakarta NO.36 tahun 2013 }\end{array}$ & $\begin{array}{l}\text { Penertiban area sepanjang kali, sungai, dan } \\
\text { waduk }\end{array}$ \\
\hline
\end{tabular}




\begin{tabular}{ll}
\hline \multicolumn{1}{c}{ Aturan dan Kebijakan } & \multicolumn{1}{c}{ Isi Aturan dan Kebijakan } \\
\hline $\begin{array}{l}\text { Peraturan Daerah No.1 tahun 2014 tentang } \\
\text { Rencana Detail Tata Ruang dan Peraturan Zonasi }\end{array}$ & $\begin{array}{l}\text { Peruntukkan Lahan : } \\
\text { RDTR : Zona Pemerintah Daerah } \\
\text { Eksisting : Hunian }\end{array}$ \\
\hline $\begin{array}{l}\text { Peraturan Daerah No.8 tahun 2007 tentang } \\
\begin{array}{l}\text { Larangan, Pemakaian Tanpa Izin yang Berhak atau } \\
\text { Kuasanya }\end{array}\end{array}$ & $\begin{array}{l}\text { Penguasa daerah dapat mengambil tindakan- } \\
\text { tindakan untuk menyelesaikan pemakaian tanah }\end{array}$ \\
\hline $\begin{array}{l}\text { UU No.1 tahun 2011 tentang Perumahan dan } \\
\text { Kawasan Permukiman }\end{array}$ & $\begin{array}{l}\text { Warga negara memiliki hak dalam menempati } \\
\text { rumah yang layak huni, sehat, dan teratur }\end{array}$ \\
\hline
\end{tabular}

Sumber : Penulis, 2019

Dalam upaya pemerintah dalam menjalankan peraturan berupa kebijakan yang telah dikeluarkan merupakan langkah yang baik ditinjau dari tujuan dikeluarkannya kebijakan tersebut sebagaimana yang dijelaskan beberapa sumber bahwa upaya ini adalah untuk meningkatkan fungsi dan perekonomian kawasan serta penghidupan yang lebih baik untuk warga terdampak namun perlu dilihat bagaimana proses pelaksanaan kebijakan tersebut harus sesuai dengan aturan agar dapat semua pihak yang terlibat di dalamnya dapat merasakan manfaat dan terwujudnya tujuan dari kebijakan tersebut bukan sebaliknya.

\section{Tugas dan Peran Aktor dalam Proses Kebijakan Relokasi Pasar Ikan Penjaringan}

Tugas dan Peran dari masing-masing aktor ini akan dilihat dari pihak pelaksana (pemerintah), warga, dan LSM. Tugas pelaksana dalam kebijakan ini dibahas pada rapat yang diselanggarakan oleh pemprov. Berdasarkan tugas dari masing-masing aktor ini akan dianalisis mengenai kesesuaian antara tugas dan peran pelaksana pada saat pelaksanaan Berikut merupakan hasil analisis mengenai peran dari masing-masing pihak yang terkait.

Tabel 4. Tugas dan Peran Aktor dalam Proses Relokasi Pasar Ikan Penjaringan

\begin{tabular}{|c|c|c|}
\hline SUBSTANSI & TUGAS & PERAN PELAKSANAAN \\
\hline $\begin{array}{l}\text { Gubernur DKI } \\
\text { Jakarta (beserta } \\
\text { jajarannya) }\end{array}$ & $\begin{array}{l}\text { - Pembuat Kebijakan } \\
\text { - Pelaksana } \\
\text { - Pengawasan }\end{array}$ & $\begin{array}{l}\text { Mengawasi pelaksanaan kebijakan relokasi } \\
\text { melalui pemkot }\end{array}$ \\
\hline Bappeda & $\begin{array}{l}\text { - Pengawasan } \\
\text { - Rencana Pembangunan }\end{array}$ & $\begin{array}{l}\text { Bappeda tidak secara langsung terlibat. } \\
\text { Peran bappeda pada saat pasca } \\
\text { penggusuran }\end{array}$ \\
\hline $\begin{array}{l}\text { Dinas Perumahan } \\
\text { Rakyat dan } \\
\text { Kawasan } \\
\text { Permukiman }\end{array}$ & $\begin{array}{l}\text { - Pelaksana } \\
\text { - Pengawasan } \\
\text { - Menyediakan Alternatif Tempat } \\
\text { Tinggal } \\
\text { - Koordinator antar Dinas Daerah, } \\
\text { Suku Dinas, dan Pihak terkait } \\
\text { - Pendataan dan Pengundian terkait } \\
\text { penempatan Rumah Susun }\end{array}$ & $\begin{array}{l}\text { - Dinas perumahan dalam hal ini telah } \\
\text { melaksanakan tugasnya dengan baik } \\
\text { - Beberapa kali turun langsung ke Pasar } \\
\text { Ikan untuk berhadapan dengan warga } \\
\text { - Menyediakan Rusunawa dan saling } \\
\text { berkoordinasi dengan pihak lainnya } \\
\text { terkait pemindahan warga Pasar Ikan ke } \\
\text { rusun. }\end{array}$ \\
\hline Dinas Pendidikan & $\begin{array}{l}\text { - Memfasilitasi pemindahan } \\
\text { sekolah } \\
\text { - Mengurus pemindahan terkait KJP }\end{array}$ & $\begin{array}{l}\text { - Dua kali melakukan pendataan } \\
\text { pemindahan sekolah anak } \\
\text { - Tidak semua berhasil dipindahkan }\end{array}$ \\
\hline
\end{tabular}




\begin{tabular}{|c|c|c|}
\hline SUBSTANSI & TUGAS & PERAN PELAKSANAAN \\
\hline Dinas Kesehatan & $\begin{array}{l}\text { - Memantau Kesehatan baik fisik } \\
\text { dan mental warga selama proses } \\
\text { relokasi berlangsung } \\
\text { - Menjamin fasilitas kesehatan } \\
\text { warga di Rusunawa } \\
\text { - Melakukan trauma healing pasca- } \\
\text { penggusuran }\end{array}$ & $\begin{array}{l}\text { - Tidak adanya pemantauan mengenai } \\
\text { kesehatan warga terdampak selama } \\
\text { proses relokasi berlangsung. } \\
\text { - Pemantauan kesehatan fisik warga hanya } \\
\text { ketika warga telah dipindahkan ke } \\
\text { rusunawa serta mengadakan trauma } \\
\text { healing. }\end{array}$ \\
\hline Dinas Sosial & $\begin{array}{l}\text { - Membantu warga kelompok } \\
\text { khusus (perempuan, lansia, } \\
\text { berkebutuhan khusus dan anak- } \\
\text { anak) untuk mendapatkan hak- } \\
\text { haknya } \\
\text { - Mengadakan pelatihan-pelatihan } \\
\text { dalam rangka memperdayakan } \\
\text { masyarakat }\end{array}$ & $\begin{array}{l}\text { - Menjaga warga kelompok khusus pada } \\
\text { proses eksekusi } \\
\text { - Berkoordinasi dengan dinas perumahan } \\
\text { terkait penempatan unit untuk kelompok } \\
\text { khusus } \\
\text { - Pelatihan-pelatihan kepada warga }\end{array}$ \\
\hline
\end{tabular}

Dinas Perhubungan $\begin{aligned} & \text { Memfasilitasi pemindahan barang } \\ & \text { (truk) dan warga (bus) }\end{aligned}$

Dinas perhubungan telah melaksanakan tugasnya dengan baik dimana dinas berkoordinasi dengan satpol PP dan Dinas Perumahan terkait pemindahan. Kekurangan Truk.

TNI dan Polri mengamankan dan mengawasi selama proses relokasi berlangsung dimulai dari awal dikerluarkan Surat Pemberitahuan hingga pasca relokasi

Walikota Jakarta Utara merupakan Pelaksana yang memegang peran penting. Pihak pemkot telah melaksanakan tugasnya dengan baik dan berperan aktif selama pelaksanaan kebijakan.

- Mengawasai dan memantau

- Mengkoordinasi antara Sudin dengan Dinas Daerah
Utara (beser

Satuan Polisi
Pamong Praja
(Satpol PP) Jakarta
Utara

- Berkoordinasi dengan TNI Polri untuk menertibakan warga

- Membantu pemindahan barang

- Berkoordinasi dengan Dinas Perumahan dan Kecamatan terkait pemerintah. pemindahan

- Pelaksana

\section{Kecamatan} Penjaringan

- Sosialisasi dengan warga

- Melakukan pendekatan persuasive kepada warga

- Melakukan pendataan

- Koordinasi dengan Dinas Daerah dan pihak lain yang terkait

Kelurahan Penjaringan pendataan

- Mengawasi warga selama berjalannya program

- Berkoordinasi dengan Satpol PP terkait memindahkan barang
- Pihak kecamatan dan kelurahan sudah menjalankan tugasnya dengan sangat baik. Pihak kelurahan dan kecamatan ini dapat dikatan sebagai "team sibuk" karena merupakan pihak yang menjadi perantara antara warga dan pemerintah tingkat kota maupun provinsi.

- Kinerja kelurahan dan kecamatan ini dinilai sangat baik karena turut aktif terlibat di lapangan dari awal persiapan hingga pasca relokasi dilakukan.

PPSU telah melaksanakan tugasnya dengan baik yaitu memindahkan barang warga menuju rusunawa. 


\begin{tabular}{|c|c|c|}
\hline SUBSTANSI & TUGAS & PERAN PELAKSANAAN \\
\hline Warga & $\begin{array}{l}\text { Warga terdampak, Ketua RW } 004 \\
\text { dan beberapa tokoh masyarakat } \\
\text { lainnya memperjuangkan hak } \\
\text { warganya dengan melakukan usaha } \\
\text { negosiasi dengan pihak Pelaksana }\end{array}$ & $\begin{array}{l}\text { Warga terdampak kebijkana relokasi Pasar } \\
\text { Ikan Penjaringan ini dibantu oleh beberapa } \\
\text { tokoh masyarakat seperi Ketua RW (Hi. } \\
\text { Aswah) dan Ibu Upik (Mantan warga Pasar } \\
\text { Ikan dan HAMI) sama-sama } \\
\text { memperjuangkan hak-haknya. }\end{array}$ \\
\hline LSM & $\begin{array}{l}\text { Membantu warga dalam } \\
\text { meperjuangkan hak-haknya }\end{array}$ & $\begin{array}{l}\text { LSM yang membantu warga dalam } \\
\text { mengajukan banding terkait kebijakan } \\
\text { relokasi di Pasar Ikan dibantu oleh } \\
\text { Himpunan Advokat Muda Indonesia (HAMI) } \\
\text { dan Lembaga Bantuan Hukum (LBH) }\end{array}$ \\
\hline
\end{tabular}

Sumber : Wawancara, 2019

Dari hasil di atas dapat disimpulkan bahwa masing-masing pihak telah mengetahui tugas dan wewenangnya masing-masing dan melaksanakan tugasnya dengan baik walaupun terdapat tiga Dinas yang belum melaksanakan tugasnya (tulisan yang di bold pada tabel 4.) terkait memfasilitasi pemindahan sekolah, kesehatan serta terkait kekurangan truk untuk pemindahan barang yang mana berdampak terhadap pelaksanaan relokasi di Pasar Ikan Penjaringan menjadi kurang optimal.

\section{Koordinasi dalam Proses Kebijakan Relokasi Pasar Ikan Penjaringan}

Dalam analisis koordinasi ini terdapat beberapa komponen yang akan dianalisis yaitu mengenai sumber daya selama proses kebijakan dilaksanakan, komunikasi antar semua pihak yang terlibat, sikap pelaksana untuk melihat pemahaman dan ketaatan pelaksana terhadap aturan selama pelaksanaan kebijakan serta melihat bagaimana pengaruh peran dari masingmasing pihak dalam pelaksanaan kebijakan relokasi, kemudian analisis antara prosedur dalam pelaksanaan relokasi untuk mengetahui keselarasan antara ketentuan yang ada dengan proses yang terjadi di lapangan. Berikut tabel mengenai Sumber Daya, Komunikasi, serta Slkap Pelaksana dalam Proses Relokasi Pasar Ikan Penjaringan:

Tabel 5. Faktor yang Mempengaruhi Proses Relokasi Pasar Ikan Penjaringan

\begin{tabular}{|c|c|c|}
\hline VARIABEL & KRITERIA & PELAKSANAAN \\
\hline \multirow[t]{3}{*}{$\begin{array}{l}\text { Sumber } \\
\text { Daya }\end{array}$} & $\begin{array}{l}\text { a. Manusia (Staff) : } \\
\text { - Kualitas : Keterampilan, } \\
\text { dedikasi, profesionalitas, dan } \\
\text { kompetensi di bidangnya } \\
\text { - } \text { Kuantitas : Dapat melingkupi } \\
\text { seluruh kelompok sasaran }\end{array}$ & $\begin{array}{l}\text { - Jumlah sumberdaya manusia pelaksana } \\
\text { dalam melaksanakan kebijakan relokasi } \\
\text { telah memadai karena setiap instansi yang } \\
\text { terlibat telah memiliki keterampilan dan } \\
\text { kompetensi di bidangnya masing-masing } \\
\text { sehingga mampuh menjalankan tugas } \\
\text { dengan baik. Untuk melihat kecukupan } \\
\text { kuantitas dapat dilihat pada proses dimana } \\
\text { jumlah pelaksana sudah dapat melingkupi } \\
\text { kelompok sasaran. }\end{array}$ \\
\hline & $\begin{array}{l}\text { b. Anggaran (Budgetary) : } \\
\text { - Anggaran harus bisa mendanai } \\
\text { jalannya sebuah program }\end{array}$ & $\begin{array}{l}\text { - Anggaran yang dialokasikan untuk } \\
\text { pelaksanaan kebijakan telah memadai } \\
\text { karena setiap instansi telah memiliki } \\
\text { anggarannya masing-masing }\end{array}$ \\
\hline & $\begin{array}{l}\text { c. Fasilitas (Facility) : } \\
\text { Keadaan fasilitas fisik yang layak } \\
\text { seperti Gedung, tanah, dan peralatan } \\
\text { yang menunjang program }\end{array}$ & $\begin{array}{l}\text { - Beberapa fasilitas yang disediakan kurang } \\
\text { memadai seperti truk untuk pemindahan } \\
\text { barang warga serta terdapat beberapa } \\
\text { fasilitas rusunawa yang rusak. }\end{array}$ \\
\hline Kom & $\begin{array}{l}\text { a. Transformasi : } \\
\text { - Komunikasi yang dilakukan dari } \\
\text { dan ke segala arah (horizontal - }\end{array}$ & $\begin{array}{l}\text { - Penyampaian informasi mengenai kebijakan } \\
\text { kepada setiap instan (pelaksana) berjalan } \\
\text { dengan optimal. Penyampaian informasi }\end{array}$ \\
\hline
\end{tabular}




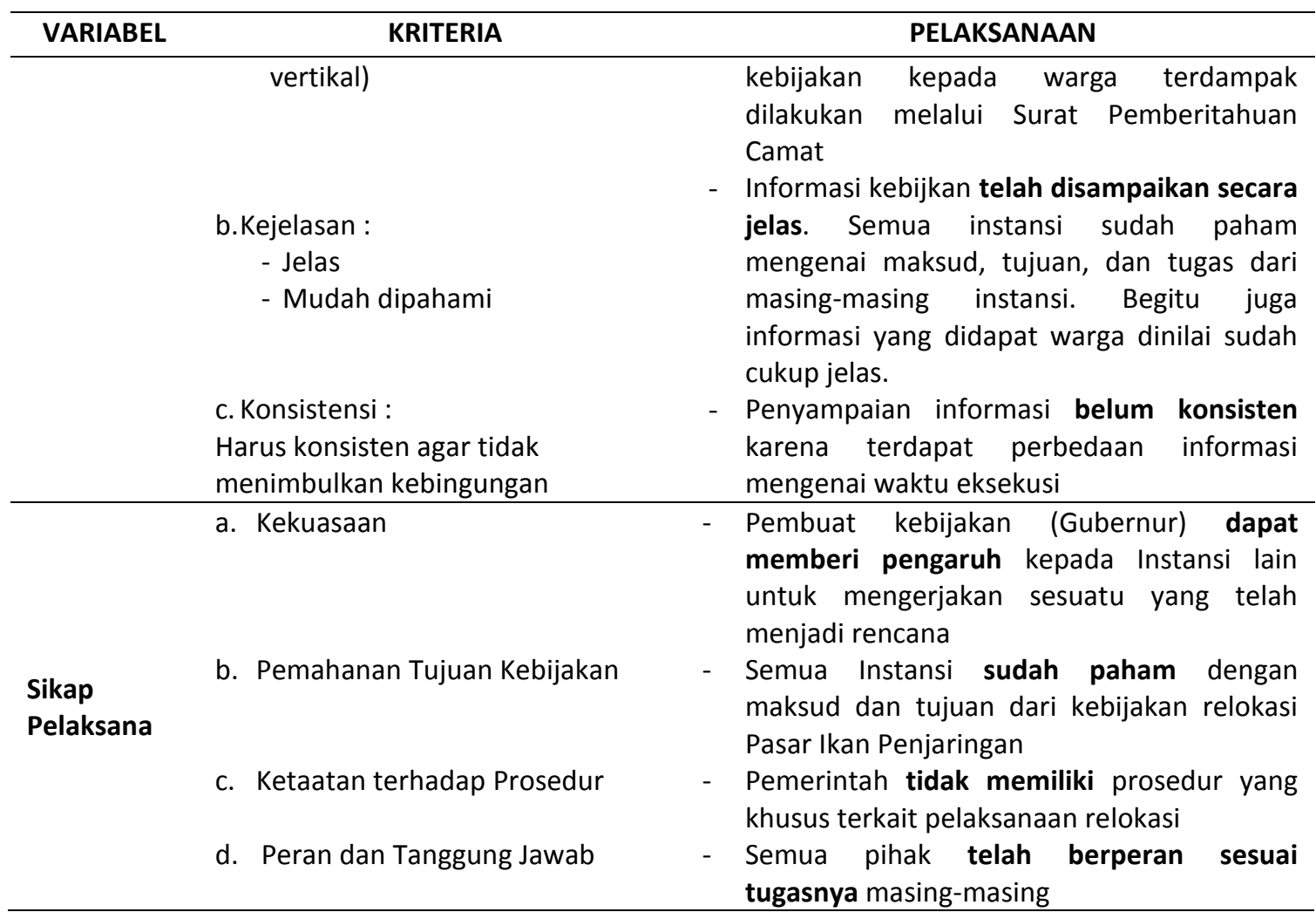

Sumber : Wawancara, Olahan Penulis, 2019

Dari pembahasan di atas diketahui bahwa sumber daya manusia dan anggaran yang disediakan sudah memadai namun untuk sumber daya fasilitas dinilai belum memadai hal ini dikarenakan oleh ketidakcukupan truk pengangkut barang. Namun untuk fasilitas dalam rusun sudah terbilang cukup baik namun memang terdapat beberapa unit yang fasilitasnya rusak.

Komunikasi yang terjadi antar pelaksana (komunikasi horizontal) dinilai sudah cukup baik namun komunikasi yang terjadi antara warga dengan pelaksana masih kurang baik. Namun, sikap pelaksana selama pelaksanaan dinilai sudah cukup baik dalam menjalankan tugas. Semua instansi paham mengenai tujuan kebijakan sehingga dalam pelaksanaan semua tindakan yang diambil berjalan searah.

Selanjutnya mengenai pelaksanaan relokasi Pasar Ikan Penjaringan berdasarkan proses kebijakan relokasi Pasar Ikan Penjaringan dengan prosedur dari United Nation mengenai Basic Principles and Guidelines on Development-Based Evictions dan Peraturan Presiden No.71/2012 tentang Penyelenggaraan Tanah Bagi Pembanguanan untuk Kepentingan umum, serta Peraturan Kepala BPN RI No.5 tentang Petunjuk Teknis Pengadaan Tanah (Dapat dilihat di tabel 1. Dan tabel 2.).

Dalam pelaksanaannya terdapat beberapa prosedur yang seharusnya ada pada saat pelaksanaan relokasi namun tidak dilakukan. Pelaksanaan yang tidak sesuai dengan prosedur adalah tidak adanya musyawarah penentuan lokasi sehingga penentuan lokasi mengenai batas-batas lokasi yang digusur telah ditentukan oleh pemerintah tanpa mengikutsertakan warga di dalamnya. Selain itu tidak adanya penilaian dampak gusur karena warga menempati lahan milik pemerintah.

Berdasarkan prosedur yang ada dikatakan bahwa sebelum pelaksanaan penggusuran semua warga yang terdampak sudah harus di relokasi ke lokasi tujuan relokasi namun pada pelaksanaan di lapangan belum semua warga terdampak telah terelokasi ke rusunawa sehingga hal ini berdampak pada saat pelaksanaan penggusuran karena warga Pasar Ikan menghalangi proses penggusuran. Waktu eksekusi yang dilaksanakan di Pasar Ikan dilaksanakan pada saat Ujian Nasional berlansung (Senin, 11 April 2016) hal ini tentu 
melanggar prosedur pelaksanaan karena pelaksanaan penggusuran tidak boleh dilaksanakan pada saat hari-hari tertentu.

Setelah pelaksanaan penggusuran warga telah dipindahkan ke Rusunawa telah dijamin fasilitas-fasilitas pendukung serta jaminan-jaminan lainnya. Keadaan fisik rusunawa yang ditempati warga Pasar Ikan terdapat kerusakan di beberapa unit (Rusunawa Marunda) sedangkan Rusunawa Rawa Bebek pada saat itu belum selesai dibangun sehingga warga harus menempati rusun lajang rawa bebek yang tipe-nya tidak sesuai untuk keluarga. Setelah pindah warga diberikan beberapa pelatihan oleh pihak Dinas Perumahan yang bekerja sama dengan UPRS dan Dinas Sosial terkait pelatihan-pelatihan keterampilan untuk warga. Namun kegiatan tersebut dinilai tidak efektif karena hanya dilakukan beberapa kali saja. Berikut adalah tabel proses pelaksanaan relokasi Pasar Ikan Penjaringan :

Tabel 6. Proses Relokasi Pasar Ikan Penjaringan

VARIABEL PELAKSANAAN

\section{a. Pra Penggusuran}

- Kajian Perencanaan

- Sosialisasi

- Musyawarah

- Tempat Tujuan Relokasi

- Penilaian Dampak Gusur

- Relokasi
- Kajian telah dilakukan oleh tim ahli

- Sosialisasi pelaksana dilakukan melalui rapat di tingkat provinsdi dan kota.

Sosialisasi yang dilakukan kepada warga dalam bentuk Surat Pemberitahuan Camat (door-to-door)

- Tidak adanya musyawarah terkait penentuan lokasi relokasi dengan warga (tidak ada partisipasi masyarakat)

- Ditentukan oleh Dinas dan Suku Dinas Perumahan.

Pra-Penggusuran : Rusun Marunda dan Rawa Bebek

Pasca-Penggusuran : Rusun Tipar Cakung dan Kapuk Muara

- Tidak ada penilaian dampak gusur (tanah milik pemerintah)

- Belum semua warga terelokasi pada saat eksekusi berlangsung

b. Penggusuran/eksekusi

- Pengawasan

(Pelaksana)

- Tidak melanggar HAM

- Waktu Eksekusi
- Pengawasan secara langsung dilakukan oleh pihak Walikota, Kecamatan dan Kelurahan

- Penggusuran secara paksa dianggap melanggar HAM

- Waktu ekseskusi dilaksanakan pada saat Ujian Nasional berlangsung

\section{c. Pasca Penggusuran}

- Menjamin ketersediaan kebutuhan warga

- Menjamin perlingungan kelompok tertentu

- Tempat relokasi layak huni

- Pemerintah telah menjamin kebutuhan warga

- Penempatan unit untuk kelompok tertentu ditempatkan di lantai 1 untuk memudahkan akses

- Rusunawa Rawa Bebek : Masih belum rampung sehingga warga menempati rusun lajang yang mana tidak cocok untuk keluarga

- Rusunawa Marunda : terdapat beberapa fasilitas yang rusak

- Tidak adanya kompensasi (lahan ilegal)

Sumber : Wawancara, Dokumen, Olahan Penulis

Dari keseluruhan uraian di atas dapat disimpulkan bahwa proses sosialisasi pemerintah mengenai kebijakan kepada warga sudah cukup baik karena warga paham mengenai isi kebijakan. Faktor yang menghambat adalah kepatuhan dari warga terdampak hal ini 
dikarenakan sikap pemerintah yang dianggap otoriter dalam mengambil keputusan (kurangnya komunikasi). Pada proses eksekusi kurang berjalan lancar akibat belum semua warga dipindahkan ke rusunawa. Faktor penghambatnya adalah kurangnya sumberdaya fasilitas terkait mobilisas serta sikap dari pelaksana yang mempengaruhi penerimaan masyarakat terkait kebijakan relokasi. Kurang optimalnya pelaksanaan pasca-penggusuran disebabkan oleh pelatihan yang dilakukan hanya beberapa kali dan dirasa warga tidak efektif karena tidak dapat menggantikan pekerjaan mereka yang lama.

\section{KESIMPULAN DAN SARAN Kesimpulan}

Dari ketiga tahap tersebut dapat dikatakan bahwa pemerintah sebagai pelaksana belum mengikuti prosedur dalam melaksanakan relokasi sesuai standar karena terdapat beberapa tahap selama proses yang tidak dilaksanakan hal ini dipengaruhi oleh beberapa faktor salah satunya karena belum adanya prosedur yang jelas dari Pemerintah Kota maupun Provinsi terkait relokasi.

Selain itu faktor lain yang dapat mempengaruhi proses relokasi Pasar Ikan Penjaringan adalah Sumber daya Sumber daya yang dimiliki oleh pelakasana dalam proses kebijakan relokasi Pasar Ikan masih kurang namun hanya pada sumber daya fasilitias (terkait kurangnya moda transportasi pemindahan barang warga). Faktor lainnya adalah komunikasi, komunikasi horizontal yang terjadi antar pelaksana sudah cukup baik hal ini dilihat dari koordinasi antar pelaksana selama proses relokasi namun komunikasi vertikal antara pelaksana dan warga dinilai masih kurang. Selain kedua fator tersebut adapalula faktor sikap Pelaksana diamana adanya sikap kekuasaan yang tinggi yang dapat mempengaruhi ketaatan pelaksana lain dalam mengikuti rencana. Selain itu semua instansi yang terlibat telah memahami pelaksana mengenai tujuan kebijakan serta tugas dan peran masing-masing sehingga pelaksanaan relokasi di Pasar Ikan sudah sesuai dengan tugas masing-masing pihak.

\section{Saran}

Memeperbaiki sistem pelaksanaan dari sebuah kebijakan sangat diperlukan agar penerapan kebijakan tersebut dapat mencapai hasil yang dapat membawa kesejahteraan bagi masyarakat. Dari hasil penelitian yang telah dilakukan peneliti terdapat beberapa saran agar pelaksanaan relokasi di DKI Jakarta kedapannya menjadi lebih baik, yaitu :

a. Dalam melakukan persiapan terkait kajian awal sebelum menentukan tindakan yang akan diambil pada suatu kawasan perlu adanya musyawarah dengan warga sebelum menentukan mengenai penggusuran suatu lahan sehingga mungkin terdapatnya alternative lain selain penggusuran walaupun apabila penggusuran wajib dilakukan warga dapat menerima keputusan tersebut karena pelaksana telah bersama-sama dengan warga untuk mencari alternatif tersebut (partisipasi masyarakat)

b. Pendekatan yang dilakukan dengan warga harus dilakukan secara intens dan perlunya kehadiran pembuat kebijakan di dalamnya bukan hanya pihak kecamatan dan kelurahan saja.

c. Pemerintah Provinsi atau Kota harusnya memiliki prosedur tentang pelaksanaan relokasi di DKI Jakarta sehingga perencanaan relokasi dapat dilakukan sesuai standar prosedur yang berlaku.

d. Dinas perhubungan seharusnya menyediakan truk tambahan sebelum ekseskusi dilaksanakan karena sebelum ekseskusi dilaksanakan banyak warga yang akan memutuskan untuk pindah dari lokasi sehingga tidak menyebabkan kekurangan fasilitas terkait mobilisasi.

e. Pemerintah perlu mengadakan pelatihan /kursus serta job fair untuk meningkatkan kapasitas produktif dari warga untuk menyediakan kesempatan kerja untuk mereka. Upaya-upaya ini akan membantu mereka untuk mendapatkan pekerjaan yang stabil dan lebih baik dan memungkinkan warga untuk meningkatkan standar hidup mereka. 


\section{REFERENSI}

(n.d.). Undang-Undang Republik Indonesia Nomor 1 Tahun 2011 tentang Perumahan dan Kawasan Permukiman. Jakarta, DKI Jakarta, Indonesia.

Bank, A. D. (1998). Policy on Involuntary Resettlement. Manila: Asian Development Bank.

Grindle, M. S. (1980). Politics and Policy Implementation in the Third World. New Jersey: Princenton University Press.

Handayaningrat, S. (2016). Pengantar Studi Ilmu Komunikasi dan Manajemen. Jakarta: Gunung Agung.

Kawasan Pasar Ikan di Penjaringan, Jakarta Utara. (2016).

Maruti, S. K. (2013). Responsivitas Pelayanan. Kantor Pertanahan Kota Salatiga dalam Implementasi Program Larasita.

Nawawi, H. (2001). Metode Penelitian Bidang Sosial. Yogyakarta: Universitas Gadjah Mada.

Rangkuti, F. (2002). Riset Pemasaran. Jakarta: Gramedia Pustaka Utama.

Semiawan, C. R. (2010). Metode Penelitian Kualitatif. Gramedia Widiasarana Indonesia.

Sugiyono. (2008). Metode Penelitian Kuantitatif, Kualitatis dan R\&D. Bandung: Alfabet.

Sumardjono, M. S. (2005). Kebijakan Pertanahan. Jakarta: PT. Kompas Media Nusantara.

Sutoyo, A. (2009). Pemahaman Individu (Observasi, Checklist, Interview, Kuesioner dan Sosiometri). Yogyakarta: Pustaka Pelajar.

Syafruding, A. (1993). Pengaturan Koordinasi Pemerintah di Daerah. Bandung: Citra Aditya Bhakti.

T. Hani, H. (2003). Manajemen Cetakan Kedelepan Belas. Yogyakarta: BPFE Yogyakarta.

Van Meter, Donal dan Van Horn, Carl E. (1975). The Policy Implementation Process Conceptual Frame Work. Journal Adminiastration and Society. 
